\title{
Effect of trans-zeatin riboside application on growth of banana (Musa AAA Simmonds) cv. Williams in the juvenile phase
}

\section{Efecto de la aplicación de trans-zeatina ribósido sobre el crecimiento de banano (Musa AAA Simmonds) cv. Williams en etapa juvenil}
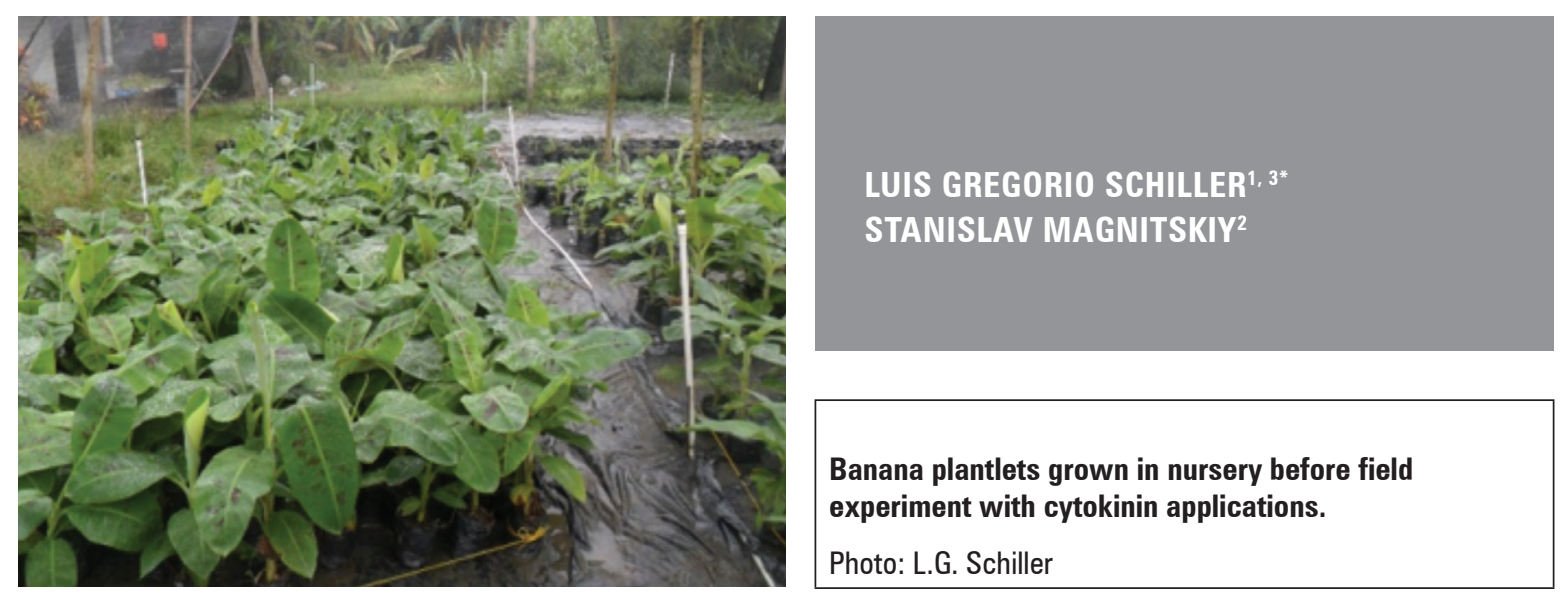

Banana plantlets grown in nursery before field experiment with cytokinin applications.

Photo: L.G. Schiller

\section{ABSTRACT}

Cytokinins are physiologically active adenine derivatives that are vital to the regulation of various developmental processes in plants, such as vegetative growth and flower induction. The objective of this study was to understand how the application of cytokinin trans-zeatin riboside affects growth in banana (Musa AAA Simmonds) cv. Williams plants during the vegetative phase on two farms located in the production zone of the Magdalena province, Colombia. The effect of trans-zeatin riboside applications at doses of $0.00,0.05,0.25$, or $0.45 \mathrm{mg} \mathrm{L}^{-1}$ via foliar spraying was evaluated, with 15 days between the applications, starting with transplant to the field and lasting until 10 weeks of growth. The treatment $0.05 \mathrm{mg} \mathrm{L}^{-1}$ of cytokinin resulted in increases in the plant growth variables, such as height in $\mathrm{V}$, pseudostem diameter, leaf width, and leaf area.

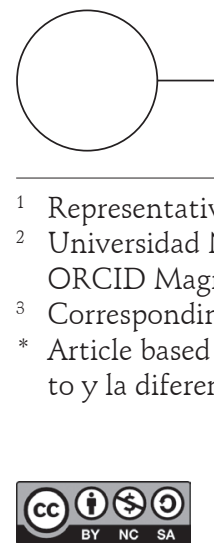

Additional key words: hormone; cytokinin; meristem; Musaceae.

Representative of Fyffes, Provincia Valverde, Mao (Dominican Republic). ORCID Schiller, L.G.: 0000-0002-9529-6398 Universidad Nacional de Colombia, Facultad de Ciencias Agrarias, Departamento de Agronomía, Bogota (Colombia). ORCID Magnitskiy, S.: 0000-0002-3715-1932

Corresponding author. lgschillerf@unal.edu.co

Article based on the MSc thesis of the first author "Efecto de la aplicación de trans-zeatina ribósido sobre el crecimiento y la diferenciación floral en banano (Musa sp.) variedad Williams". 


\section{RESUMEN}

Las citoquininas son compuestos fisiológicamente activos derivados de adenina, vitales para la regulación de varios procesos de desarrollo en plantas, tal como el crecimiento vegetativo y la inducción floral. El objetivo de este trabajo fue conocer como la aplicación de citoquinina trans-zeatina ribósido afecta el crecimiento vegetativo de plantas de banano (Musa AAA Simmonds) cv. Williams en dos fincas ubicadas en la zona bananera del departamento de Magdalena, Colombia. Se evaluó el efecto de la aplicación de trans-zeatina ribósido en dosis de 0,00; 0,05; 0,25 o 0,45 mg L ${ }^{-1}$ vía foliar, con espacio entre aplicación de 15 días iniciando en el momento de trasplante de plantas al sitio definitivo y hasta 10 semanas de crecimiento. El tratamiento de plantas con 0,05 $\mathrm{mg} \mathrm{L}^{-1}$ de citoquinina resultó en incrementos en variables del crecimiento, tales como altura a la V, diámetro del seudotallo, ancho foliar y área foliar.

Palabras clave adicionales: hormona; citoquinina; meristemo; Musaceae.

Received for publication: 21-02-2019 Accepted for publication: 31-07-2019

INTRODUCTION

In Colombia, banana cultivation occupied 85,700 ha in 2016, of which 8,635 ha were in the municipalities of the banana production zone, Magdalena province, which generated $290,428 \mathrm{t}$, corresponding to $14.2 \%$ of domestic production. This production had an approximate value of 2,093,985 million US dollars (Agronet, 2018). One of the tasks necessary for a better yield is adequate edaphic and foliar fertilization of the crop that is done properly. Phytohormones could be used as a complement to mineral nutrition, acting on the metabolic functions of plants (Albán, 2014). Among the main phytohormones, cytokinins stimulate plant growth and development (Mok, 2018). Within the group of cytokinins, agricultural applications in the field exist for kinetin, zeatin, zeatin riboside, trans-zeatin, cis-zeatin, dihydrozeatin, 6-benzylaminopurine, and other natural and synthetic compounds (Sánchez and Mira, 2013). The physiological benefits of cytokinin applications to plants include stimulation of leaf growth, regulation of shoot and root development, stimulation of respiration and photosynthesis, flower induction, and fruit growth (Jordán and Casaretto, 2006; Bar and Ori, 2014; Mok, 2018).

In Musaceae, according to the BBCH scale of development, the vegetative meristem has a characteristic arrangement of leaves with a spiral form, absence of lateral shoots and absence of internode growth (Nalina et al., 2006). The reproductive phase in this crop begins with changes occurring in the vegetative meristem, which undergoes metabolic shifts that transform it into the floral bud (Sánchez and Mira, 2013; Landrein et al., 2018). In banana, flower induction depends on the number of emerged leaves (Rodríguez et al., 2012), which, in turn, relays on external factors and internal regulators, such as hormone activity (Chaurasia et al., 2017).

An important phase in the life cycle of banana plants is inflorescence development, where climatic conditions including temperature, wind, and precipitation can delay flower differentiation and affect bunch formation (Galán et al., 2012). Air temperature influences the transpiration rate, as well as duration of life cycle and bunch weight in banana plants through the control that it exerts on leaf metabolism (Robinson and Galán, 2012). Precipitation is one of the main climatic factors that determine banana crop development (Santos et al., 2018); plants can quickly adapt to a water deficit in soil, which would further severely reduce the rates of leaf emission and bunch development (Galán et al., 2012). The effects of edaphoclimatic conditions on flower induction and differentiation in Musaceae could be explained, at least in part, by the hormonal interactions in plants (Robinson and Galán, 2012).

According to previous studies, applications of plant growth regulators to Musaceae might shorten the juvenile phase of growth and accelerate flower differentiation. Thus, the application of auxins at a rate $100 \mathrm{mg} \mathrm{L}^{-1}$ have stimulated floral differentiation in banana; however, treatments with naphthalene acetic acid with doses exceeding $500 \mathrm{mg} \mathrm{L}^{-1}$ have caused fruit malformations (Lima et al., 2016). At the same time, applying gibberellins at doses of 500 to $1,000 \mathrm{mg}$ 
$\mathrm{L}^{-1}$ has caused elongation of the pseudostem (Lima et al., 2016). Likewise, during vegetative growth, spraying brassinolide at 3-6 g L-1 on banana (Musa sp. cv. Berangan) plantlets significantly has increased plant height, pseudostem diameter, leaf number, leaf area, and fresh and dry weight of plants (Zakaria et al., 2018). Applications of cytokinins, such as benzyladenine, at doses of 20 to $100 \mathrm{mg} \mathrm{L}^{-1}$ have increased the growth of corm in banana plants (Lahav and Gottreich, 1984). According to Muriel (2012), cytokinins influenced cell division, retarded senescence, and increased growth, fruit weight, and number of exportable hands of banana.

In general, the effects of cytokinin applications on banana growth in the field are poorly studied. López (2014) evaluated applications of cytokinins, comparing two fertilizer alternatives injected into the pseudostem of Musa sp. These treatments had no positive effect on the plant growth; one of the treatments contained kinetin at $1 \mathrm{~g} \mathrm{~L}^{-1}$ (López, 2014). In the vegetative propagation of Musa sp. with 6-benzylaminopurine (BAP) and indoleacetic acid (IAA), the best treatment was $30 \mathrm{mg} \mathrm{L}^{-1} \mathrm{BAP}$, which positively influenced shoot formation in each studied variety, followed by the concentration $30 \mathrm{mg} \mathrm{L}^{-1} \mathrm{BAP}+10 \mathrm{mg}$ $L^{-1}$ IAA (Canchignia et al., 2008). Albán (2014) found positive effects from cytokinin applications on leaf emission, increasing the pseudostem diameter in cv. Grand Naine; in addition, foliar applications of algae extracts rich in cytokinins were a source of hormones and essential carbohydrates, which resulted in better yield and harvest quality (Albán, 2014). Aspiazu (2014) compared the applications of various hormones, concluding that gibberellins $\left(20 \mathrm{mg} \mathrm{L}^{-1}\right)$ and brassinosteroids $\left(2 \mathrm{mg} \mathrm{L}^{-1}\right)$ positively influenced plant growth and increased leaf length in banana. However, when $20 \mathrm{mg} \mathrm{L}^{-1}$ gibberellin, $20 \mathrm{mg} \mathrm{L}^{-1}$ cytokinin, and $2 \mathrm{mg} \mathrm{L}^{-1}$ brassinosteroids were jointly applied, no significant increases were found in the pseudostem diameter,number/weight of roots or leaf width (Aspiazu, 2014). Langford et al. (2017) studied the macropropagation of banana plants in a nursery with BAP at two concentrations: $10^{-2} \mathrm{M}$ and $5 \times 10^{-3} \mathrm{M}$, with the following treatments: immersion of corms in BAP solutions for $30 \mathrm{~min}$, immersion of corms in coconut water for $30 \mathrm{~min}$, and placing the corms in a substrate of rice husk. The treatments with BAP and coconut water (a natural source of cytokinins) induced sprouting in the corms and a loss of the apical dominance (Langford et al., 2017).
The use of phytohormones gibberellins, brassinosteroids, and cytokinins, individually or mixed, is mainly studied in the propagation of Musa sp., such as in the asexual multiplication of corms planted in the field (Canchignia et al., 2008). However, no reports were found in the literature on the use of trans-zeatin riboside as a possible factor increasing vegetative growth in banana. The objective of the present research was to evaluate the effect of applications of trans-zeatin riboside (cytokinin) on the vegetative growth of banana cv. Williams in the Magdalena Province of Colombia.

\section{MATERIALS AND METHODS}

\section{Experiment locations}

This field study was carried out on two farms: El Polo located at 10 $53^{\prime} 39.905^{\prime \prime} \mathrm{N}$ and 74'11'58.214" W and La Paz 1 located at 10'53'37.17' $\mathrm{N}$ and $74^{\circ} 11^{\prime} 54.623^{\prime \prime} \mathrm{W}$, both at an altitude of $20 \mathrm{~m}$ a.s.l. in the town El Mamey (Colombia), and characterized with a tropical dry climate according to Holdridge (Aguirre, 2012). This study was conducted between October 2016 and January 2017. The duration of the field experiment was 13 weeks.

The climatic data in the field were obtained from the meteorological station El Enano of the Colombian meteorological institute INAT (E1 Mamey). The average air temperature was $26.8^{\circ} \mathrm{C}$, with monthly precipitation of $12.8 \mathrm{~mm}$ and an average wind speed of $14.54 \mathrm{~km} \mathrm{~h}^{-1}$. In general, the climatic conditions were typical for areas of commercial banana production on the Atlantic coast of Colombia, which are adequate for the development of banana plants (Sánchez and Mira, 2013). The two farms, where the plants were established, differed in physical and chemical characteristics of the soil. The soil type on both was Inceptisoles (Soil Survey Staff, 2010). The marked differences between the two locations were in soil texture (La Paz 1: Loamy, El Polo: Sandy Loam); pH (La Paz 1: 5.8, El Polo: 7.7), C/N ratio (La Paz 1: 11, El Polo: 12.2), and cation exchange capacity (La Paz 1: 16.9, El Polo: 9.4 meq $100 \mathrm{~g}^{-1}$ ) of the soil arable layer.

\section{Field crop management}

Banana (Musa AAA Simmonds) cv. Williams plants, propagated in vitro, were employed. Prior to transplant to the field, the plants were hardened in a 
shade house, in which water and mineral nutrients were supplied as edaphic and foliar applications for 6 weeks.

The plants were established in the field at week zero with 4 leaves and $25 \mathrm{~cm}$ maximum height at the time of transplant; the planting density was $2.40 \mathrm{~m}$ between the plants and $2.40 \mathrm{~m}$ between the rows. In the sowing sites, $60 \mathrm{~g}$ per plant of Rafos ${ }^{\circledR}$ (Yara, Colombia) edaphic fertilizer were applied. The plant management practices employed by Torres (2016) for conventional banana produced for export in Colombia were used.

The irrigation with sprinkling was done between weeks 0 and 13 according to the needs of the crop. Between weeks 0 and 6 after planting, $6 \mathrm{~mm} \mathrm{ha}^{-1}$ of irrigation water were applied daily, divided in two irrigation periods. Starting from week 7 after planting, $5 \mathrm{~mm} \mathrm{ha}^{-1}$ water were applied per day; for this, a subfoliar spray system was used, with 2014 Senninger ${ }^{\circledR}$ sprinklers spaced at $10 \mathrm{~m}$ by $10 \mathrm{~m}$.

Every 15 d during weeks $0-12$, edaphic fertilizers were applied at a rate of $60-120 \mathrm{~g} /$ plant. On the La Paz 1 farm, Rafos ${ }^{\circledR}$ was applied at $60 \mathrm{~g} /$ plant (week 0), Ammonium sulfate at $90 \mathrm{~g} /$ plant (week 2), Amidas ${ }^{\circledR}$ (Yara, Colombia) at $90 \mathrm{~g} /$ plant (week 4), Calcium Nitrate at $90 \mathrm{~g} /$ plant (week 6), and Aboteck ${ }^{\circledR}$ (Yara, Colombia) at $90 \mathrm{~g} /$ plant (weeks 8 and 10) and $120 \mathrm{~g} /$ plant (week 12). On the El Polo farm, the same products were used but the doses were different: 60 $\mathrm{g} /$ plant (week 2), $60 \mathrm{~g} /$ plant (week 4), and $90 \mathrm{~g} /$ plant (week 12). Every $15 \mathrm{~d}$ starting from week 1, foliar fertilizers (Wuxal ${ }^{\circledR}$, Bayer, Colombia) were applied using a $20 \mathrm{~L}$ mechanical back pump, prepared with $100 \mathrm{~cm}^{3}$ of molasse water.

The mechanical weed control (Quintero-Pertúz and Carbonó-Delahoz, 2015) was done every 15 d. Every week, the lower leaves affected by Black Sigatoka (Mycosphaerella fijiensis) were eliminated until week 5. Starting from week 6 , only the fraction of the leaf affected by Black Sigatoka was removed. The products applied to control Black Sigatoka were Sico-Dithane ${ }^{\circledR}$ (3 ${ }^{\text {rd }}$ week), Siganex-Dithane ${ }^{\circledR}$ (5 $5^{\text {th }}$ week), OpusDithane ${ }^{\circledR}\left(8^{\text {th }}\right.$ week), and Voley-Dithane ${ }^{\circledR}\left(12^{\text {th }}\right.$ week). The suckers were cut off the plants every $6^{\text {th }}$ week.

\section{Applications of trans-zeatin riboside}

The hormone trans-zeatin riboside (t-ZR), 95\% purity, was obtained from Sigma ${ }^{\circledR}$ laboratories (Sigma-Aldrich, St. Louis, MO), stored according to the manufacturer recommendations at $-20^{\circ} \mathrm{C}$, and diluted in type 1 water before the applications to reach the dose required in each treatment. Four treatments were tested on the plants via foliar spraying: water (control, $0 \mathrm{mg} \mathrm{L}^{-1}$ trans-zeatin riboside), $0.05 \mathrm{mg} \mathrm{L}^{-1}$, $0.25 \mathrm{mg} \mathrm{L}^{-1}$, or $0.45 \mathrm{mg} \mathrm{L}^{-1}$ of trans-zeatin riboside. Applications were made every $15 \mathrm{~d}$ (Fig. 1) using a manual back pump with a 21 pound pressure regulator and yellow nozzle (GEF-REPCar, 2011), spraying the plant leaves and pseudostem. The treatments started at planting in the field and continued until completing 6 applications of the hormone in each plant. The applications of cytokinin ended at week 10 after transplant (Fig. 1).

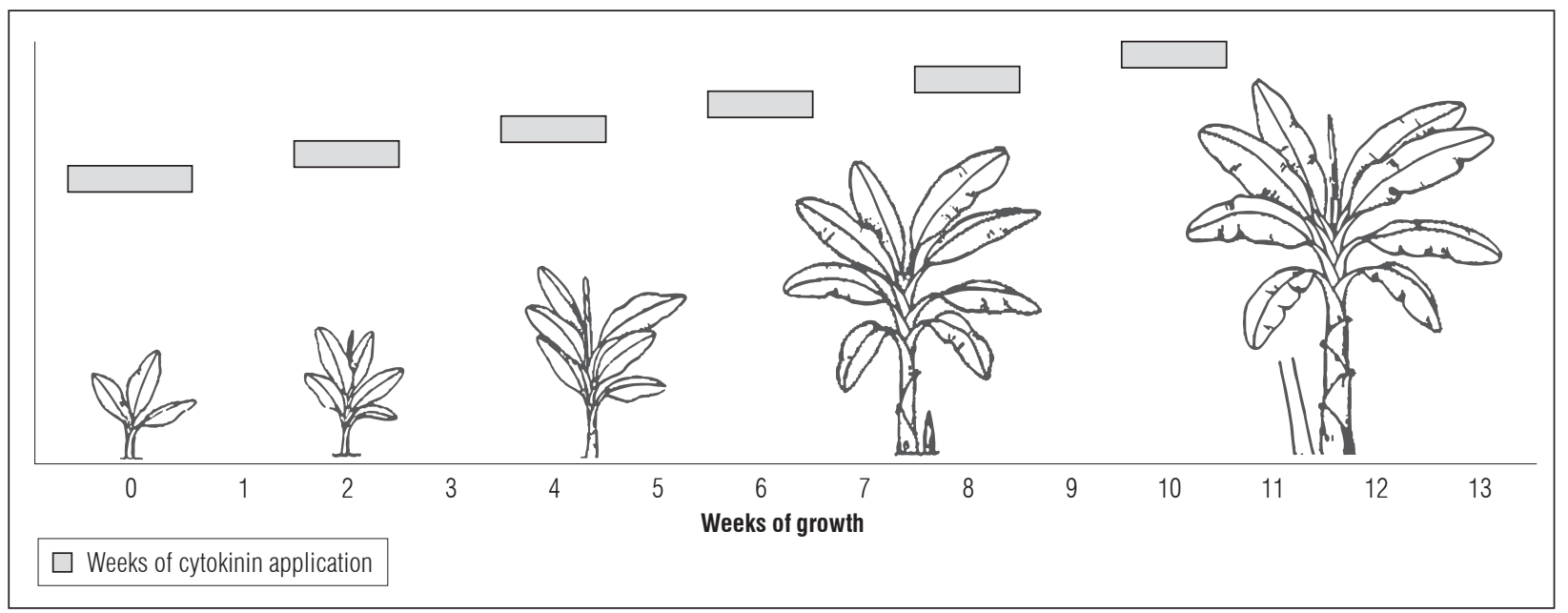

Figure 1. Development of banana plants and the time of cytokinin applications. 


\section{Data collection in the field}

The experiment had a bi-factorial randomized block design with six replicates (one plant per replicate) on the La Paz 1 and El Polo farms. A total of 360 plants were planted; in each location, 20 plots were arranged, of which, 15 plots had 6 plants and the other five plots had 18 plants.

From week 1 and up to week 13, in each research plot, biometric data were collected weekly on each plant: leaf length (in each leaf), leaf width (in each leaf), pseudostem diameter, and plant height. From the ground to the bifurcation point of the pseudostem, the height of the plant $(\mathrm{cm})$ denominated as "height in V" was measured with a tape measure. The diameter of the pseudostem was measured with a caliper, $5 \mathrm{~cm}$ from the ground. The area of each leaf was calculated with the following equation (1) (Martínez et al., 2015):

$$
L A=\Sigma L \times A \times 0.80
$$

where $L A$ is leaf area $\left(\mathrm{cm}^{2}\right), L$ is length of the leaf blade from the apex of the leaf to its base $(\mathrm{cm})$, and $A$ is width of the leaf blade in the middle part $(\mathrm{cm})$.

\section{Statistical analysis}

The statistical analysis used one-way analysis of variance, with a Tukey test at a confidence level of 95\%. For all cases, the assumption of normality of the Shapiro-Wilk residuals and Bartlett's variance equality was tested. The area under the curve was calculated using the AUDPS function of the Agricolae ${ }^{\circledR}$ package
(Simko and Piepho, 2012). To identify statistically significant differences between the means of the variables, the Student t test $(P<0.05)$ was used.

\section{RESULTS AND DISCUSSION}

\section{Plant height}

On the farm La Paz 1, treatments with 0 and 0.05 $m g L^{-1}$ trans-zeatin riboside resulted in a significantly larger plant height in $\mathrm{V}$ (height of the plant from the ground level up to point of the pseudostem bifurcation), as compared to the treatments with 0.25 and $0.45 \mathrm{mg} \mathrm{L}^{-1}$ cytokinin (Fig. 2A). The tallest plants were obtained in the treatment with $0.05 \mathrm{mg} \mathrm{L}^{-1}$ cytokinin, with a $46.3 \mathrm{~cm}$ average height (average value of measurements between weeks 1 and 13) (Fig. 2A). On El Polo, the four treatments had different heights, with the tallest plants, $46.9 \mathrm{~cm}$ average height, obtained after applications of $0.05 \mathrm{mg} \mathrm{L}^{-1}$ cytokinin (Fig. 2B). Apparently, this indicated that trans-zeatin riboside, at a rate of $0.05 \mathrm{mg} \mathrm{L}^{-1}$, stimulated cell growth (cell division or/and cell elongation), which resulted in an increased height. These results are consistent with the research of Ortiz et al. (2013), in which cytokinin applications generated a faster growth in Musa sp. In banana, the pseudostem diameter and heightto-circumference ratio (HCR) for tall cultivars as well as HCR for medium-height cultivars are known as good predictors of inflorescence emergence since these variables have exhibited linear or quadratic

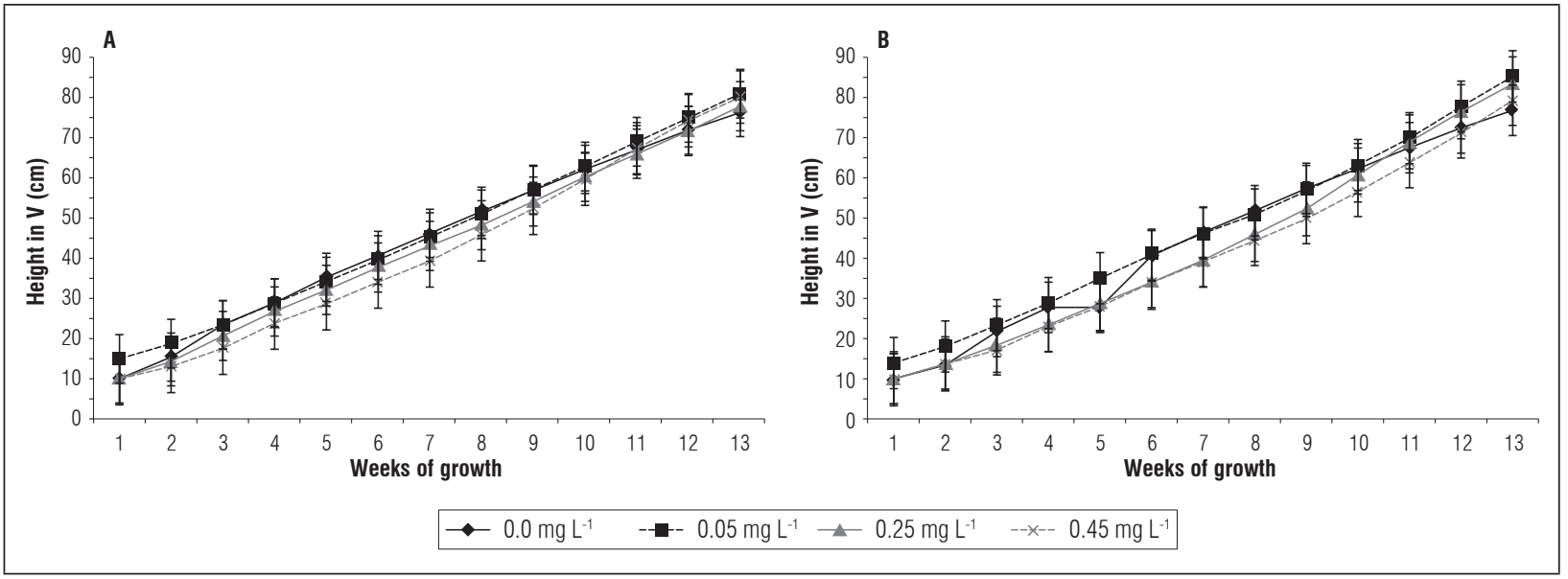

Figure 2. Height in $\mathbf{V}$ of banana plants cv. Williams sprayed with different doses of trans-zeatin riboside during vegetative growth on the farms La Paz 1 (A) and El Polo (B). The results are presented as mean \pm standard error. 
relationships with the number of days from planting to inflorescence emergence (Vinson et al., 2018).

\section{Pseudostem diameter}

The diameter of the pseudostem was assessed as a variable of plant development; all treatments increased the pseudostem diameter on the farms La Paz 1 and El Polo over time. However, the plants grown on La Paz 1 (Fig. 3A) differed in the confidence intervals for the treatments 0 and $0.05 \mathrm{mg} \mathrm{L}^{-1}$, as compared to the treatments 0.25 and $0.45 \mathrm{mg} \mathrm{L}^{-1}$; the treatment $0.05 \mathrm{mg} \mathrm{L}^{-1}$ yielded the highest average pseudostem diameter, $4.6 \mathrm{~cm}$ (average value of measurements between 1 and 13 weeks). On the El Polo farm, the plants treated with $0.05 \mathrm{mg} \mathrm{L}^{-1}$ cytokinin had the largest average pseudostem diameter, $4.6 \mathrm{~cm}$ (Fig. 3B). These results indicate that the best treatment in both locations was $0.05 \mathrm{mg} \mathrm{L}^{-1}$ trans-zeatin riboside, which was the lowest dose. The increase in pseudostem diameter could indicate a higher cellular activity, which implies increases in dry mass, higher demand for nutrients, and a higher meristematic activity (Sánchez and Mira, 2013). In Musa sp., a large pseudostem diameter correlates with a higher plant resistance to breakage by wind and reflects a plant's ability to sustain the bunch (Gonçalves et al., 2018), as well as correlates with a higher storage capacity in the pseudostem for water and carbohydrates (Sánchez and Mira, 2013; Shivashankar et al., 2016).

\section{Leaf growth variables}

The leaf length did not present significant differences between the treatments (Fig. 4), while on La Paz
1, the leaves tended to be the longest with the 0.25 $\mathrm{mg} \mathrm{L}^{-1}$ cytokinin application, with an average length value of $58.5 \mathrm{~cm}$ (average value of measurements between 1 and 13 weeks) and, on El Polo, the best treatment was $0.45 \mathrm{mg} \mathrm{L}^{-1}$, with a length value of $63.1 \mathrm{~cm}$ (Fig. $4 \mathrm{~A}$ and $\mathrm{B}$ ).

At the same time, the leaf width significantly differed between the treatments (Fig. 5). On La Paz 1, the widest leaves were obtained in the treatment with $0.25 \mathrm{mg} \mathrm{L}^{-1}$ cytokinin, where the average leaf width reached $28.3 \mathrm{~cm}$ (average value of the measurements between 1 and 13 weeks) (Fig. 5A). On El Polo, the largest leaf width was recorded in the $0.05 \mathrm{mg} \mathrm{L}^{-1}$ treatment, with a $29.9 \mathrm{~cm}$ average value (Fig. 5B). As a result, the plants on the El Polo farm presented the widest leaves. This effect from the cytokinins was consistent with the results of Bar and Ori (2014), who indicated that leaf blade development depends on light and cytokinins for maintaining balance with auxins and stimulation of meristem activity. Cytokinins are known to stimulate cell division and cell expansion in leaves (Mok, 2018). In a review carried out by Landrein et al. (2018) on Arabidopsis, expression of the $C Y C D 3$ gene is required for development of new leaves until reaching the leaf size typical of this species.

The leaf area reflected a relationship between leaf length and width, presenting no significant differences between the locations or between the treatments on La Paz 1 and El Polo. The highest average leaf area on $\mathrm{La}$ Paz 1 was reached with $0.25 \mathrm{mg} \mathrm{L}^{-1}$ cytokinin, $1473 \mathrm{~cm}^{2}$ (average value of measurements between weeks 1 and 13) and, on the El Polo farm, the $0.05 \mathrm{mg} \mathrm{L}^{-1}$ cytokinin treatment resulted in the

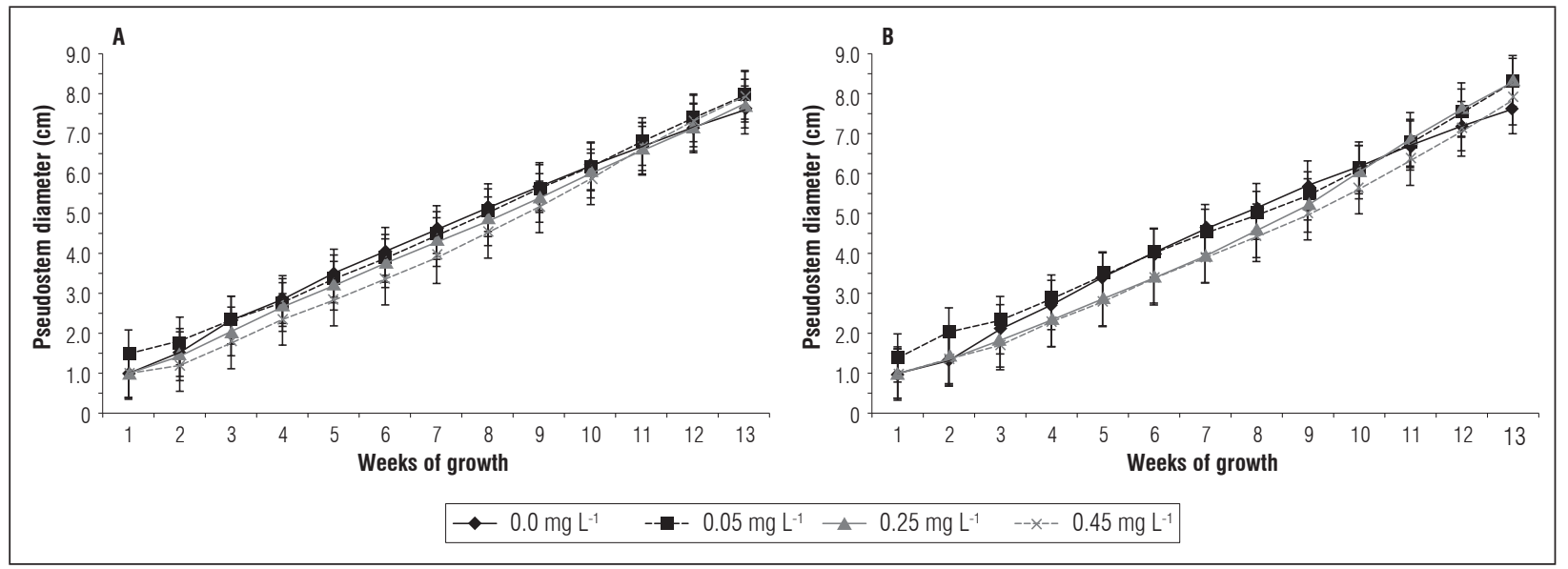

Figure 3. Pseudostem diameter of banana plants cv. Williams sprayed with different doses of trans-zeatin riboside during vegetative growth on the farms La Paz 1 (A) and El Polo (B). The results are presented as mean \pm standard error. 


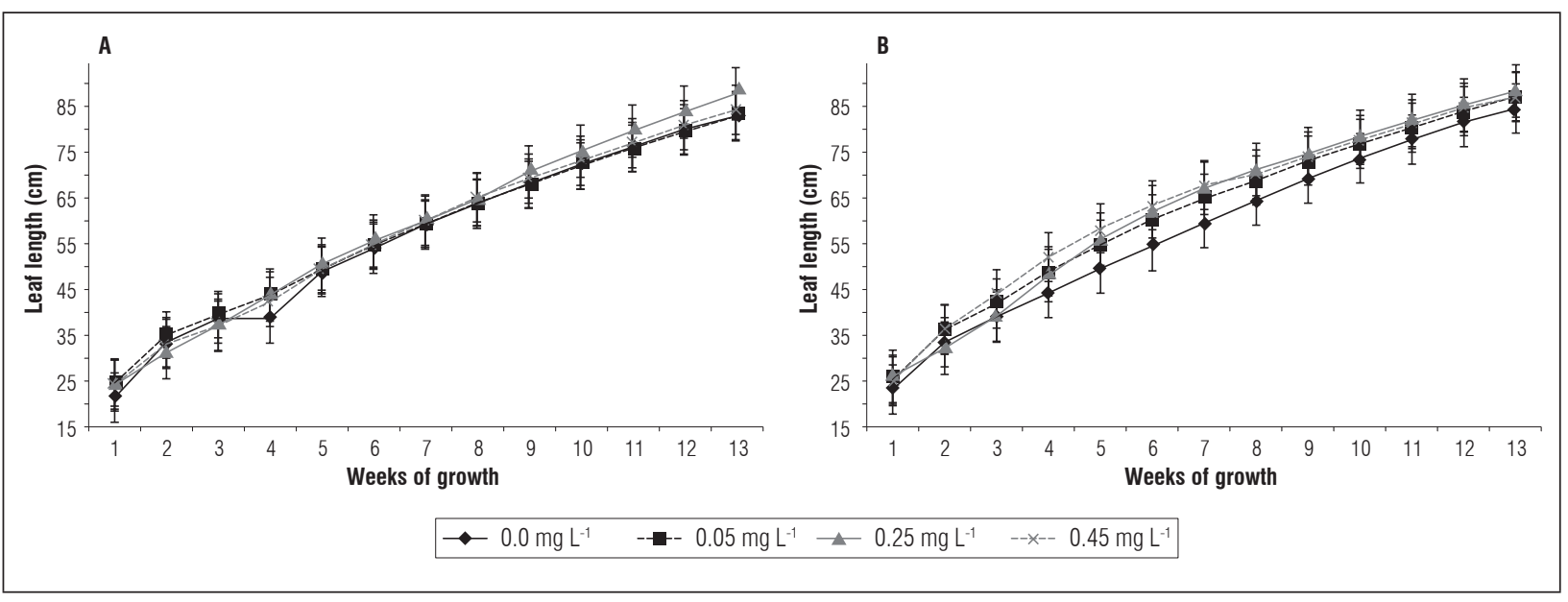

Figure 4. Leaf length of banana plants cv. Williams sprayed with different doses of trans-zeatin riboside during vegetative growth on the farms La Paz 1 (A) and El Polo (B). The results are presented as mean \pm standard error.

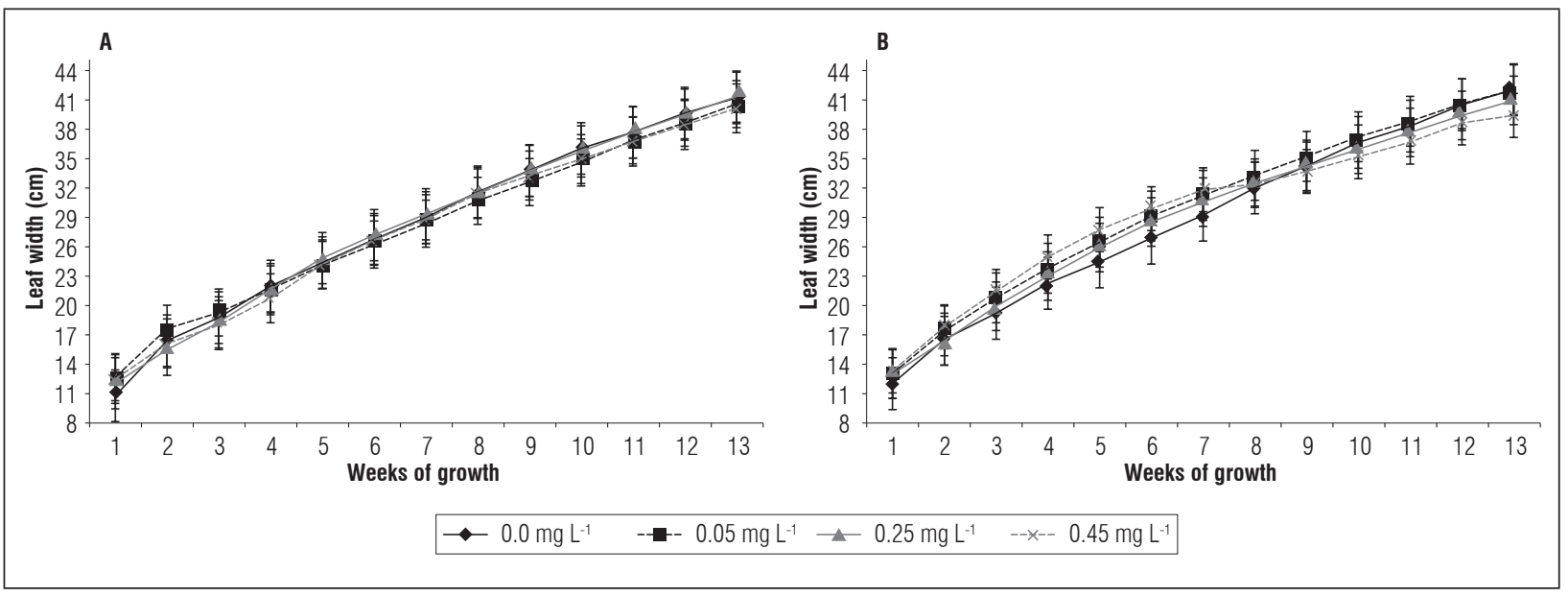

Figure 5. Leaf width of banana plants cv. Williams sprayed with different doses of trans-zeatin riboside during vegetative growth on the farms La Paz 1 (A) and El Polo (B). The results are presented as mean \pm standard error.

highest average leaf area, $1616 \mathrm{~cm}^{2}$ (Fig. $6 \mathrm{~A}$ and B). It can be speculated that the phytohormone spraying on the leaves/pseudostem affected expression of the LOG genes in the apical meristem region of the stem, where the stem cells reside. In Arabidopsis, the LOG4 gene is expressed in the L1 layer of the vegetative meristem; LOG genes encode enzymes that convert inactive cytokinin ribosides into active forms, providing a localized source of active cytokinin in the vegetative meristem (Landrein et al., 2018). Cytokinins could increase leaf size because of the high rate of cell expansion, yielding a higher shoot biomass (Skalák et al., 2019) and delayed leaf senescence (Gan, 2014). In banana, direct relationships between leaf area and yield were previously established (Robinson and Galán, 2012); these data are important since the growth and formation of banana bunches depends on the number and physiological activity of functional leaves (Rodríguez et al., 2012).

The results of the present study indicated that the application of trans-zeatin riboside positively influenced the development of banana plants without a reduction in growth or presenting deformations in plant morphology, such as the ones reported by Albán (2014). In our research, the treatment that generated, on average, the highest leaf expansion was $0.05 \mathrm{mg} \mathrm{L}^{-1}$ trans-zeatin riboside, as compared with 


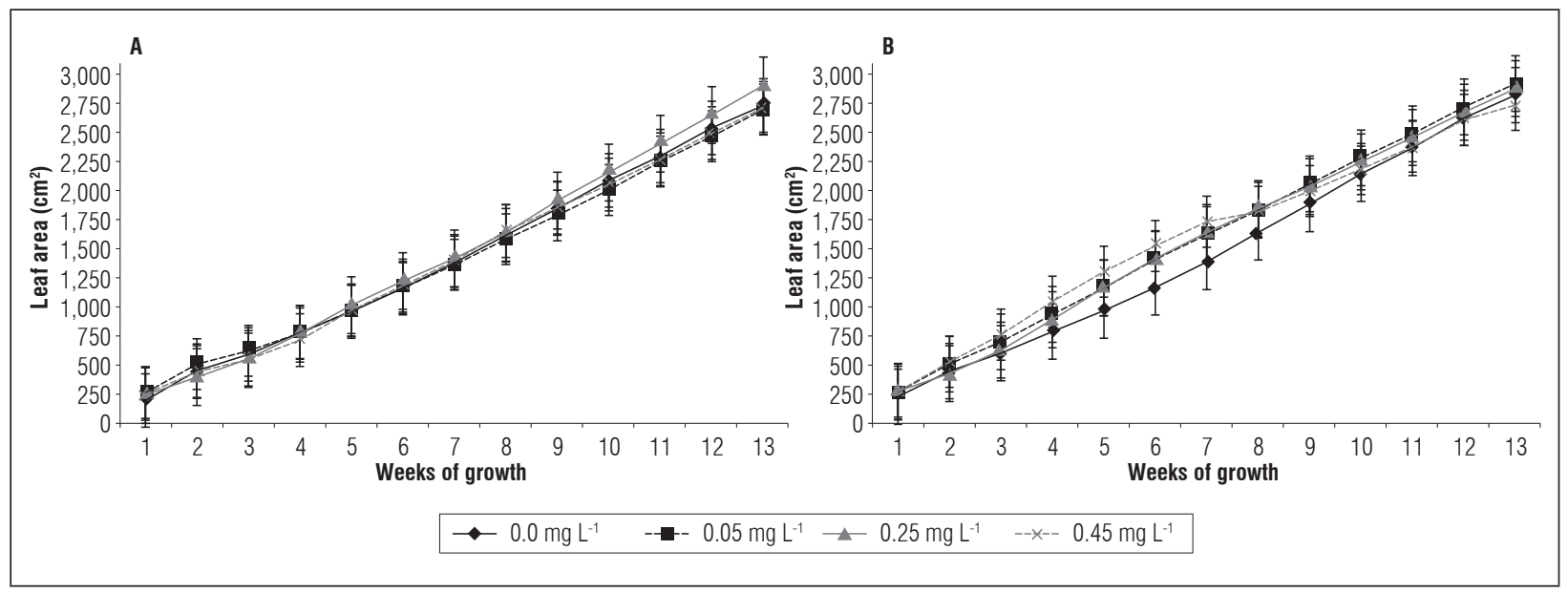

Figure 6. Leaf area of banana plants cv. Williams sprayed with different doses of trans-zeatin riboside during vegetative growth on the farms La Paz 1 (A) and El Polo (B). The results are presented as mean \pm standard error.

the other evaluated treatments. These findings agree with the data reported for applications of other rates/ formulae of cytokinins, which tended to increase the growth rate of plants, resulting in increases in height, pseudostem diameter, leaf length and leaf width in Musa sp. plants (Albán, 2014; Aremu et al., 2014; Aspiazu, 2014).

The practical importance of faster vegetative growth in Musaceae at the commercial level includes a reduction of the juvenile phase of growth, which favors a change from vegetative to reproductive growth, accelerates flower differentiation, and reduces the number of weeks required for flowering and initiation of bunch formation. The applications of transzeatin riboside on Musa sp. plants during vegetative development could be explored for possibly counteracting the effect of stress caused by biotic and abiotic factors (Schäfer et al., 2015; Miller et al., 2017), which might further increase production levels on commercial plantations.

\section{CONCLUSIONS}

The growth variables height in $\mathrm{V}$, leaf width, leaf area, and pseudostem diameter presented statistically significant differences, depending on the level of trans-zeatin riboside sprayed on the banana plants $\mathrm{cv}$. Williams during 10 weeks of growth in the field. The low doses of trans-zeatin riboside, such as $0.05 \mathrm{mg} \mathrm{L}^{-1}$, generated the best results for plant height at V, pseudostem diameter, leaf width and leaf area.

\section{Acknowledgments}

The authors greatly acknowledge the Facultad de Ciencias Agrarias, Universidad Nacional de Colombia, Bogotá for help with research development and Cooperativa de Bananero de Rio Frío (COOBAFRíO) of the Magdalena Province for offering the space to carry out the research on the farms La Paz 1 and El Polo. The authors extend their gratitude to Dr. Gerardo Cayón Salinas and Dr. Victor Julio Flórez (Universidad Nacional de Colombia) for their vital suggestions and comments in presenting the results of this research.

Conflict of interests: this manuscript was prepared and reviewed with the participation of the authors, who declare that there is no exists conflict of interest that puts the validity of the presented results at risk.

\section{BIBLIOGRAPHIC REFERENCES}

Agronet. 2018. Producción nacional por producto. In: Ministerio de Agricultura y Desarrollo Rural de Colombia, http://www.agronet.gov.co/Paginas/ProduccionNacionalProducto.aspx; consulted: October, 2018.

Aguirre, S., N. Piraneque, and J. Menjivar. 2012. Relación entre las propiedades edafoclimáticas y la incidencia de sigatoka negra (Mycosphaerella fijiensis Morelet) en la zona bananera del Magdalena-Colombia. Rev. Investig. Agrar. Ambient. 3(2), 13-25. Doi: 10.22490/21456453.970

Albán, E.E. 2014. Evaluación de la eficacia de citoquinina (Cytokin) y un inductor carbónico (Carboroot) en tres 
dosis y en dos épocas en el rendimiento de banano de exportación, en una plantación en producción variedad Gran Enano, cantón Quiniende de las provincias de Esmeraldas. Undegraduate thesis. Escuela Superior Técnica de Chimborazo, Chimborazo, Ecuador.

Aremu, A.O., L. Plačková, M.W. Bairu, O. Novák, L. Szüčová, K. Doležal, J.F. Finnie, and J. Van Staden. 2014. Endogenous cytokinin profiles of tissue-cultured and acclimatized 'Williams' bananas subjected to different aromatic cytokinin treatments. Plant Sci. 214, 88-98. Doi: 10.1016/j.plantsci.2013.09.012

Aspiazu, R.I. 2014. Propagación vegetativa de cebollines de banano (Musa paradisiaca) variedad Cavendish mediante la aplicación de tres hormonas en el cantón Buena Fe. Undegraduate thesis. Universidad Técnica Estatal de Quevedo, Quevedo, Ecuador.

Bar, M. and N. Ori. 2014. Leaf development and morphogenesis. Development 141(22), 4219-4230. Doi: 10.1242/ dev.106195

Canchignia, H., M. Espinoza, G. Benavides, S. Saucedo, M. Carranza, and O. Cevallos. 2008. Propagación vegetativa de plátano y banano con la aplicación de benzilaminopurina (6-BAP) y ácido indolacético (AIA). Rev. Cienc. Tecnol. 1(1), 11-15. Doi: 10.18779/cyt.v1i1.16

Chaurasia, A.K., H.B. Patil, B. Krishna, V.R. Subramaniam, P.V. Sane, and A.P. Sane. 2017. Flowering time in banana (Musa spp.), a day neutral plant, is controlled by at least three FLOWERING LOCUS T homologues. Sci. Rep. 7(1), 5935. Doi: 10.1038/s41598-017-06118-x

Galán Saúco, S., J.C. Robinson, E. Tomer, and J.W. Daniells. 2012. Current situation and challenges of cultivating banana and other tropical fruits in the subtropics. Acta Hortic. 928, 19-30. Doi: 10.17660/ ActaHortic.2012.928.1

Gan, S.S. 2014. Leaf senescence as an important target for improving crop production. Adv. Crop Sci. Tech. 2, e116. Doi: 10.4172/2329-8863.1000e116

GEF-REPCar. 2011. Mantenimiento y calibración de aspersoras manuales en pequeños cultivos de banáno y plátano. AUGURA, Medellín, Colombia.

Gonçalves, Z.S., D.D.S. Invenção, C.D.S. Ledo, C.F. Ferreira, and E.P. Amorim. 2018. Agronomic performance of plantain genotypes and genetic variability using Ward-MLM algorithm. Genet. Mol. Res. 17(1), gmr16039882. Doi: 10.4238/gmr16039882

Jordán, M. and J. Casaretto. 2006. Hormonas y reguladores del crecimiento: auxinas, giberelinas y citocininas. pp. 1-28. In: Squeo, F.A. and L. Cardemil (eds.). Fisiología vegetal. Ediciones Universidad de La Serena, La Serena, Chile.

Lahav, E. and M. Gottreich. 1984. The effect of growth hormones on banana: a review. Plant Growth Regul. 2(1), 15-30. Doi: 10.1007/BF00024092
Landrein, A., P. Fomosa-Jordan, A. Malivert, C. Schuster, D. Melnyk, W. Yang, C. Turnbull, E. Meyerowitz, J.C.W. Locke, and H. Jönsson. 2018. Nitrate modulates stem cell dynamics in Arabidopsis shoot meristems through cytokinins. Proc. Natl. Acad. Sci. USA 115(6), 13821387. Doi: 10.1073/pnas.1718670115

Langford, E., P.J. Trail, A.J. Bicksler, and R. Burnette. 2017. An evaluation of banana macropropagation techniques for producing pig fodder in Northern Thailand. Sustain. Agric. Res. 6(2), 48-57. Doi: 10.5539/sar. v6n $2 \mathrm{p} 48$

Lima, J.D., J.S. Rosa, D.E. Rozane, E.N. Gomes, and S.H. Silva. 2016. Changes in the characteristics of 'Prata' banana treated with cytokinin and gibberellin. Rev. Bras. Frutic. 38(3), e-379. Doi: 10.1590/0100-29452016379

López, Á.U. 2014. Estudio comparativo de dos alternativas nutricionales inyectadas en plantas de banano (Musa AAA), en el cantón Milagro, provincias de Guayas. Undegraduate thesis. Universidad de Guayaquil, Facultad de Ciencias Agrarias, Guayaquil, Ecuador.

Martínez, C., G. Cayón, and G. Ligarreto. 2015. Physiological attributes of banana and plantain cultivars of the Colombian Musaceae collection. Agron. Colomb. 33(1), 29-35. Doi: 10.15446/agron.colomb. v33n1.45935

Miller, R.N.G., G.S. Costa Alves, and M.A. Van Sluys. 2017. Plant immunity: unravelling the complexity of plant responses to biotic stresses. Ann. Bot. 119(5), 681-687. Doi: $10.1093 / \mathrm{aob} / \mathrm{mcw} 284$

Mok, M.C. 2018. Cytokinins and plant development: an overview. pp. 155-166. In: Mok, D.W.S. and M.C. Mok (eds.). Cytokinins: chemistry, activity and function. Reissued CRC Press, Boca Raton, FL. Doi: 10.1201/9781351071284

Muriel, F. 2012. Eficiencia de fitohormonas en el desarrollo y productividad del banano en el Urabá antioqueño. Corporación Universitaria Lasallista, Caldas, Colombia.

Nalina, L., N. Kumar, K. Soorianathasundaram, J.S. Kennedy, V. Krishnamoothy, and M. Ganga. 2006. Flower bud initiation and differentiation in plants of cv. Robusta (AAA) derived from suckers and from tissue-cultured plantlets. Infomusa 15(1-2), 24-25.

Ortiz, R., E. Moreno, and J. Valverde. 2013. Tecnología innovadora en el uso de citoquininas y giberelinas (Banana Blast ${ }^{\oplus}$ Tec) para incrementar la producción de banano. p. 142. In: Proc. XX Reunión Internacional de la Asociación para la Cooperación y Desarrollo Integral de las Musáceas (Bananos y Plátanos). Fortaleza, Brazil.

Quintero-Pertúz, I. and E. Carbonó-Delahoz. 2015. Panorama del manejo de malezas en cultivos de banano en el departamento de Magdalena, Colombia. Rev. Colomb. Cienc. Hortic. 9(2), 329-340. Doi:10.17584/ rcch.2015v9i2.4188 
Robinson, J.C. and V. Galán. 2012. Plátanos y bananas. Editorial Paraninfo, Madrid.

Rodríguez, C., D.G. Cayón, and J.J. Mira. 2012. Effect of number of functional leaves at flowering on yield of banana Grand Naine (Musa AAA Simmonds). Rev. Fac. Nac. Agron. Medellín 65(2), 6585-6591.

Sánchez, J. and J. Mira. 2013. Principios para la nutrición del cultivo del banano. AUGURA, Medellín, Colombia.

Santos, A.S., E.P. Amorim, C.F. Ferreira, and C.P. Pirovani. 2018. Water stress in Musa spp.: a systematic review. PloS One 13(12), e0208052. Doi: 10.1371/journal. pone.0208052

Schäfer, M., C. Brütting, I.D. Meza-Canales, D.K. Großkinsky, R. Vankova, I.T. Baldwin, and S. Meldau. 2015. The role of cis-zeatin-type cytokinins in plant growth regulation and mediating responses to environmental interactions. J. Exp. Bot. 66(16), 4873-4884. Doi: 10.1093/jxb/erv214

Shivashankar, S., R.P. Nachane, and S. Kalpana. 2006. Composition and properties of fibre extracted from pseudostem of banana (Musa sp.). J. Hortic. Sci. 1(2), 95-98.

Simko, I. and H.-P. Piepho. 2012. The area under the disease progress stairs: calculation, advantage, and application. Phytopathol. 102, 381-389. Doi: 10.1093/jxb/ erv214
Skalák, J., L. Vercruyssen, H. Claeys, J. Hradilová, M. Černý, O. Novák, L. Plačková, I. Saiz-Fernández, P. Skaláková, F. Coppens, S. Dhondt, Š. Koukalová, J. Zouhar, D. Inzé, and B. Brzobohatý. 2019. Multifaceted activity of cytokinin in leaf development shapes its size and structure in Arabidopsis. Plant J. 97(5), 805-824. Doi: 10.1111/tpj.14285

Soil Survey Staff. 2010. Keys to soil taxonomy. $9^{\text {th }}$ ed. USDA Soil Conservation Service, Washington D.C.

Torres, J. 2016. Absorción, distribución y acumulación de nitrógeno en banano variedad Williams en dos ciclos de producción en zona húmeda tropical. $\mathrm{PhD}$ thesis. Universidad Nacional de Colombia, Bogota.

Vinson, E.L., E.D. Coneva, J.M. Kemble, F.M. Woods, J.L. Sibley, E.G. Fonsah, P.M. Perkins-Veazie, and J.R. Kessler. 2018. Prediction of flower emergence and evaluation of cropping potential in selected banana cultivars (Musa sp.) cultivated in subtropical conditions of coastal Alabama. HortScience 53(11), 1634-1639. Doi: 10.21273/HORTSCI13290-18

Zakaria, M.A.T., S.Z. Sakimin, M.F. Ramlan, H.Z. Jaafar, A. Baghdadi, and S.N.M. Din. 2018. Morphological and physiological changes of banana (Musa acuminata cv. Berangan) to brassinolide at nursery stage. J. Trop. Plant Physiol. 10(1), 36-45. 